\title{
Immune to happiness - inflammatory process indicators and depressive personality traits
}

Monika E. Talarowska ${ }^{1}$, Małgorzata Kowalczyk ${ }^{1}$, Michael Maes ${ }^{2}$, Andre Carvalho ${ }^{3}$, Kuan-Pin Su${ }^{4}$, Janusz Szemraj5, Piotr Gałecki ${ }^{1}$

\author{
${ }^{1}$ Department of Adult Psychiatry, Medical University of Lodz, Lodz, Poland \\ 2Department of Psychiatry, Faculty of Medicine, Chulalongkorn University, Bangkok, \\ Thailand \\ ${ }^{3}$ Department of Psychiatry, University of Toronto, Toronto, Canada \\ ${ }^{4}$ Department of Psychiatry and Mind-Body Interface Laboratory (MBI-Lab), China \\ Medical University Hospital, Taichung, Taiwan \\ ${ }^{5}$ Department of Medical Biochemistry, Medical University of Lodz, Lodz, Poland
}

Submitted: 10 December 2018

Accepted: 27 January 2019

Arch Med Sci 2020; 16 (4): 848-857

DOI: https://doi.org/10.5114/aoms.2019.83146

Copyright @ 2019 Termedia \& Banach

\begin{abstract}
Introduction: Nowadays, depression is conceptualized as an immune-inflammatory and oxidative stress disorder associated with neuroprogressive changes as a consequence of peripherally activated immune-inflammatory pathways, including peripheral cytokines and immune cells which penetrate into the brain via the blood barrier, as well as nitro-oxidative stress and antioxidant imbalances. The aim of this study was to investigate whether personality traits predisposing to a depressive episode (hypochondria, dysthymic, hysteria) are associated with changes in peripheral gene expression for selected indicators of inflammation and oxidative balance.

Material and methods: One hundred four people meeting the diagnostic criteria specified for a depressive episode took part in the study. Selected scales of the Minnesota Multiphasic Personality Inventory (MMPI-2) were used to measure personality traits. Expression at the mRNA and protein level for manganese superoxide dismutase (MnSOD), myeloperoxidase (MPO), cyclooxygenase 2 (COX-2), inducible nitric oxide synthase (iNOS), and metalloproteinases 2 and 9 (MMP-2, MMP-9) was examined.

Results: Scales for the neurotic triad of the MMPI-2 test correlated significantly with the expression at the level of mRNA and protein for MnSOD, MPO and metalloproteinases 2 and 9.

Conclusions: The scales specified for the neurotic triad of the MMPI-2 test correspond substantially with the expression of MnSOD, MPO and metalloproteinases 2 and 9 at the mRNA and protein levels in the group of patients suffering from depression.
\end{abstract}

Key words: depressive disorders, personality, anxiety, neuroticism, inflammation.

\section{Introduction}

Depression is referred to as the "common cold" of the $21^{\text {st }}$ century [1]. We can understand this expression twofold. On the one hand, it emphasises the prevalence of disease symptoms in the modern world, while on the other hand it points to the immunological background of depressive disorders [2]. Over the past 40 years, many attempts have been made

\author{
Corresponding author: \\ Monika E. Talarowska PhD \\ Department \\ of Adult Psychiatry \\ Medical University \\ of Lodz \\ 159 Aleksandrowska St \\ 91-229 Lodz, Poland \\ Phone: +48603686690 \\ E-mail: talarowskamonika@ \\ wp.pl
}


to understand the biological causes of depressive symptoms. In the 1990s, monoamine theories seemed to be the gold standard, exploited by the pharmaceutical industry [3]. Over the years, however, they have proven to be insufficient and depression has become an increasingly common disease in all age groups [4, 5].

A new understanding of mood disorders, including depressive disorders, has emerged over the past three decades. Depression is conceptualized as an immune-inflammatory and oxidative stress disorder associated with neuroprogressive changes as a consequence of peripherally activated immune-inflammatory pathways, including peripheral cytokines and immune cells which penetrate into the brain via the blood barrier $[6,7]$, as well as nitro-oxidative stress and antioxidant imbalances [8, 9].

In the neurodevelopmental theory of depression, Gałecki and Talarowska [10] emphasised the importance of the earliest stages of our lives for the formation of personality traits conducive to the occurrence of a depressive episode in adult life. Human personality is a collection of typical interpersonal behaviours, subjective reactions, feelings and goals we strive for, conditioned by the functioning of branched networks of nervous connections [11]. Among the features of mental structure conducive to the appearance of depression, anxiety is mentioned as a permanent feature of functioning. According to Bukh et al. [12], the presence of personality traits typical for the so-called Cluster C (avoidant, dependent and obsessive-compulsive personality) reduces the likelihood of achieving remission of depressive disorders by $30 \%$ and increases the risk of relapse after the first episode by as much as $80 \%$ [12].

The aim of this study is to investigate whether personality traits predisposing to a depressive episode (hypochondria, dysthymic, hysteria) are associated with changes in peripheral gene expression for selected indicators of inflammation and oxidative balance (manganese superoxide dismutase (MnSOD), myeloperoxidase (MPO), cyclooxygenase 2 (COX-2), inducible nitric oxide synthase (iNOS), and metalloproteinases 2 and 9 (MMP-2, MMP-9).

We hypothesized that the severity of anxiety as a permanent personality trait and scales of the neurotic triad of the Minnesota Multiphasic Personality Inventory (MMPI-2) would be associated with an increased inflammatory response.

\section{Material and methods}

One hundred and four patients treated for recurrent depressive disorders were enrolled in the study (aged 20-60, average age (mean \pm SD) 8.22 \pm 11.56 ). The criteria for inclusion in the study were based on the diagnostic criteria for an epi- sode of depression and recurrent depressive disorders in accordance with the ICD-10 guidelines (F32.0-7.32.2, F33.0-F33.8) [13].

The subjects took part in the study during hospitalisation. Participation in the experiment did not have an impact on the applied treatment modalities (pharmacotherapy, psychotherapy). All of the patients were treated with standard antidepressive therapy: SSRIs (selective serotonin reuptake inhibitors) in standard doses The specified agents were administered in therapeutic doses, defined by Ettinger [14].

The criteria for exclusion from the trial included: history of treatment confirming psychiatric disorders other than depression in the past; presence of somatic diseases that may affect depression; trauma of the central nervous system; history of inflammatory, autoimmune and neoplastic diseases; abuse or addiction to psychoactive substances; lack of consent for participation in the trial. Qualification for participation in the experiment was performed at random without replacement sampling. All the subjects qualified for the study were native Poles from central Poland, not related to one another. Each patient gave written consent to participate in the experiment in accordance with the report approved by the Bioethics Committee of the Medical University of Lodz (approval no.: RNN/534/10/KB of 07/09/2010).

The examined subjects were divided and two groups were formed, i.e. patients diagnosed with the first episode of depression (ED-I, $n=34$ ) and patients affected by a repeated episode of the disease (recurrent depressive episode, rDE, $n=70$ ). No statistically significant differences were found between the examined groups in terms of age $(Z=0.117, p=0.507)$ or $\operatorname{sex}\left(\chi^{2}=0.221, p=0.641\right)$.

\section{Assessment of depression severity}

The Hamilton Depression Rating Scale (HDRS, HAM-D) [15], was used to evaluate severity of depression. A scoring system developed by Demyttenaere and De Fruyt [16] was applied when analysing the intensity of depressive episode symptoms.

\section{Assessment of personality traits (the Minnesota Multiphasic Personality Inventory, MMPI-2)}

The personality structure of the examined individuals was assessed using the Polish version of the MMPI-2 test developed by S. Hathaway and J. McKinley, adapted by T. Kucharski $[17,18]$. A detailed description of the MMPI-2 test was presented in one of our previous papers $[19,20]$.

In each case, an evaluation of the mental state, assessment of the severity of depressive disorders and assessment of performance of psychological 
tests were conducted by the same person, i.e. a clinical psychologist. An examination based on the application of the HDRS scale was performed twice, i.e. on the day of qualification of a specific person for the experiment and after clinical condition improvement (after 8 weeks of treatment on average). The examination with the $\mathrm{MMPI}-2$ test took place after the patients were qualified to participate in the examination.

\section{Assessment of expression at mRNA and protein levels}

The procedure of genetic analyses was described in detail in one of the papers by Talarowska et al. [20]. The blood used to conduct genetic analyses was collected (in volumes of $5 \mathrm{ml}$ ) on the day of admission to the experiment.

\section{Evaluation of selected genes' expression at the level of protein}

Total protein concentration in blood plasma of the patients was determined using the Micro BCA Protein Assay Kit (Thermo SCIENTIFIC) based on the manufacturer's recommendations. One hundred fifty $\mu \mathrm{l}$ of the reaction mixture was added to pits containing $150 \mu \mathrm{l}$ of serum, diluted 10 times in $10 \mathrm{mM}$ of phosphate buffered saline, $\mathrm{pH} 7.4$, and incubated $\left(2 \mathrm{~h}, 37^{\circ} \mathrm{C}\right)$. In order to measure protein concentration, an analytical curve for serum albumin was determined. Both the examined samples and the reference samples were made in parallel in three repetitions. Sample absorbance was measured using a Multiskan Ascent Microplate Photometer (Thermo Labsystems) at $\lambda=570 \mathrm{~nm}$ and total protein concentration was calculated from the standard curve equation.

\section{Evaluation of selected genes' expression at the level of mRNA}

\section{Total RNA isolation}

Peripheral blood was used as a material in the genotype study (in volumes of $5 \mathrm{ml}$ on EDTA). Total RNA isolation from the patients' blood samples using TRIZOL (Invitrogen Life Technologies) - an RNA extraction reagent - according to the standard acidguanidinium-phenol-chloroform method, was performed using Chomczyński's modified method. The absorbance of isolated RNA was measured using a spectrophotometer (Picodrop) at $\lambda=260$ $\mathrm{nm}$ with the aim of determining total RNA concentration. Isolated RNA was stored at a temperature of $-70^{\circ} \mathrm{C}$.

\section{Quality analysis of isolated RNA}

The quality of total RNA was checked with an Agilent RNA 6000 Nano Kit (Agilent Technolo- gies) in accordance with the manufacturer's recommendations. $1 \mu \mathrm{l}$ of RNA 6000 Nano dye was added to a test tube containing $65 \mu$ of Agilent RNA 6000 Nano gel matrix, and then centrifuged (10 min, $13000 \mathrm{xg}$ ).The gel-fluorescent dye mixture was applied on the surface of a Nano chip placed in a workstation. Then, $5 \mu$ of RNA Nano marker were added to selected pits. Isolated samples of RNA and RNA size marker were subject to denaturation $\left(2 \mathrm{~min}, 70^{\circ} \mathrm{C}\right)$, and then $1 \mu \mathrm{l}$ of the sample was pipetted to selected pits of the Nano chip, and mixed (1 min, $2400 \mathrm{rpm}$ ). The quality of isolated RNA was checked using a 2100 Bioanalyzer (Agilent Technologies). The level of degradation of total RNA was determined using an electrophoretogram and the RNA integrity number (RIN) values recorded. Only the samples with RIN values $>7$ were subject to further analysis.

A reverse transcription (RT) reaction was carried out using a TaqMan RNA Reverse Transcription Kit (Applied Biosystems) based on the manufacturer's recommendations. The samples were incubated (30 $\mathrm{min}, 16^{\circ} \mathrm{C}$ and $30 \mathrm{~min}, 42^{\circ} \mathrm{C}$ ) in a thermocycler(Biometra). Reverse transcriptase was inactivated $\left(5 \mathrm{~min}, 85^{\circ} \mathrm{C}\right)$ and the obtained $\mathrm{CDNA}$ was stored at a temperature of $-20^{\circ} \mathrm{C}$. A real-time PCR reaction was conducted using TaqMan Universal PCR Master Mix, No UNG (Applied Biosystems), according to the protocol provided by the manufacturer, delivered by Applied Biosystems. To calculate relative expression of miRNA genes, the $C t$ comparative method was used [21, 22].

\section{Statistical analysis}

Selected methods of descriptive statistics and methods of statistical reasoning were applied in the statistical analysis of the collected material. During statistical verification of the hypotheses, a two-tailed critical area was assumed.

Appropriate structural indicators, i.e. prevalence of a given trait expressed in percentage terms, were applied in the description of qualitative features in the examined group of affected patients and the control group. The arithmetic mean (M) was calculated to describe the value of average quantitative features. The range of values (with the minimum and maximum value determined) and the standard deviation (SD) were used as measures of dispersion.

The distribution of all variables was examined with the Shapiro-Wilk test. The hypothesis on the normality of distribution was rejected. The following non-parametric tests were applied with reference to non-parametric variables for statistical comparisons between the examined groups: Pearson's $\chi^{2}$ test and the Mann-Whitney $U$ test. Spearman's rank correlation coefficient was used to evaluate the correlations between the analysed 
variables. The significance level for all the statistical methods applied was set at $p<0.05$ [23]. All statistical calculations were conducted using the computer software Statistica PL, version 13.1.

\section{Results}

Sociodemographic characteristics of the studied group and the information regarding the course of the underlying disease are presented in Table I.

\section{Descriptive statistics of the analysed variables}

Statistically significant differences between the analysed groups in the intensity of the symptoms measured with the neurotic triad for the MMPI-2 test were confirmed. Significantly higher results were recorded by the patients hospitalised due to another episode of depression (Table II), which indicates the intensification of personality traits associated with anxiety reaction together with subsequent episodes of the disease. Statistically significant differences in the expression at the mRNA and the protein level were observed only for MMP-2 (Table II).

\section{Correlations}

Results of Spearman's rank correlation for the examined groups are presented in Table III. The most statistically significant correlations were observed in the patients with another episode of depression compared to those treated for the first time. Scales for the neurotic triad of the MMPI-2 test correlated significantly with the expression at the level of mRNA and protein for MnSOD, MPO and metalloproteinases 2 and 9. Red also indicates correlations close to statistical significance. The absence of significant correlations in the ED-I group may be due to its low size.

\section{Discussion}

To our knowledge, this is the first study to systematically investigate the roles of peripheral gene expression for indicators of inflammation and ox- idative balance in personality traits predisposing to a depressive episode. In our previous papers we referred to oxidative and antioxidative imbalances and immune system disorders in patients with symptoms of depression and among healthy people: MnSOD [24], MPO [25], COX-2 [26], iNOS [27], MMP-2 and MMP-9 [28]. At this point, we would like to summarise the correlations related to the functioning of the immune and emotional systems.

\section{The affective and rational system -} the basis for personality formation

Negative emotional attitudes, typical of patients with symptoms of depression, are most likely the result of an imbalance between "emotional" (structures of the limbic system with the amygdala and the hippocampus) and "motivational/regulatory" brain regions (frontal lobes, mainly the area of the prefrontal cortex of the brain) [29]. In response to negative stimuli the "emotional" brain of the individuals suffering from depression is excessively active, whereas its reaction to positive information is insufficient. On the other hand, the "motivational/regulatory" brain does not cope well with blocking and filtering unwanted and unpleasant information [30]. The described dysfunctions seem to be a permanent feature of the cognitive and emotional functioning of patients with depression. They are also likely to cause a pessimistic style of information processing (as a permanent feature of personality), characteristic for people with depressive disorders, associated with numerous ruminations of a negative emotional nature [31]. Thus, the cerebral cortex, by deciding how to deal with primary emotions coming from deeper structures, is responsible for the foundations of our personality.

\section{Emotional immunity or immune emotionality? The key to understanding depression}

The dysregulation of the immune system as an aetiological factor, but also affecting the course of depression, is no longer questionable [32, 33]. D’Acquisto [34] uses the term affective immunol-

Table I. Characteristics of the studied groups in terms of demographic features and the course of depression $(n=104)$

\begin{tabular}{|lccc|}
\hline Parameter & Mean \pm SD or $n(\%)$ & ED-I $(n=34)$ & rDE $(n=70)$ \\
\hline Age [years] & $48.22 \pm 11.56$ & $47.36 \pm 9.21$ & $50.51 \pm 8.63$ \\
\hline Women/men & $60 / 44(57.70 .40 / 42.30)$ & $17 / 17(50.00 / 50.00)$ & $43 / 27(61.43 / 38.57)$ \\
\hline HDRS-I & $24.24 \pm 6.47$ & $23.17 \pm 6.33$ & $24.61 \pm 6.52$ \\
\hline Number of depressive episodes & - & - & $7.15 \pm 3.45$ \\
\hline Duration of disease [years] & $6.89 \pm 2.53$ & $1.71 \pm 1.21$ & $9.44 \pm 3.65$ \\
\hline
\end{tabular}

HDRS I - Hamilton Depression Rating Scale on the day of qualification for the experiment, HDRS II - Hamilton Depression Rating Scale after response to the pharmacological treatment applied, ED-I - patients diagnosed with the first depressive episode, rDE - patients treated for recurrent depressive episodes. 
Monika E. Talarowska, Małgorzata Kowalczyk, Michael Maes, Andre Carvalho, Kuan-Pin Su, Janusz Szemraj, Piotr Gałecki

Table II. Descriptive statistics for the analysed variables as divided into examined groups

\begin{tabular}{|c|c|c|c|c|c|}
\hline Variable & & $\begin{array}{c}\text { All subjects } \\
(n=104) \\
\text { Mean } \pm \text { SD }\end{array}$ & $\begin{array}{c}\text { ED-I }(n=34) \\
\text { Mean } \pm \text { SD }\end{array}$ & $\begin{array}{l}\text { rDE }(n=70) \\
\text { Mean } \pm \text { SD }\end{array}$ & ED-I vs. rDE \\
\hline $\begin{array}{l}\text { Hypochondria } \\
\text { scale }(\mathrm{Hd})\end{array}$ & $\begin{array}{l}\text { High scores mean: unspecified } \\
\text { physical problems, concern } \\
\text { for own health, concentration } \\
\text { on unreal somatic problems, } \\
\text { energy deficiency, lack of } \\
\text { satisfaction, problems with } \\
\text { sleep, complaining, claiming } \\
\text { attitude }\end{array}$ & $71.81 \pm 12.86$ & $67.01 \pm 11.52$ & $74.11 \pm 12.91$ & $0.012^{*}$ \\
\hline $\begin{array}{l}\text { Depression } \\
\text { scale (D) }\end{array}$ & $\begin{array}{l}\text { High scores mean: depressive } \\
\text { mood, low self-esteem and the } \\
\text { feeling of being inappropriate, } \\
\text { worrying, lack of satisfaction } \\
\text { with life status, withdrawal }\end{array}$ & $77.31 \pm 11.39$ & $73.15 \pm 10.13$ & $79.29 \pm 11.49$ & $0.011^{*}$ \\
\hline $\begin{array}{l}\text { Hysteria scale } \\
(\mathrm{Hy})\end{array}$ & $\begin{array}{l}\text { High scores mean: poor insight } \\
\text { into life-related problems and } \\
\text { emotions, various somatic } \\
\text { fears, problems with sleep, } \\
\text { negation, claiming attitude, } \\
\text { self-concentration }\end{array}$ & $71.35 \pm 12.76$ & $65.84 \pm 12.37$ & $73.98 \pm 12.18$ & $0.001^{*}$ \\
\hline $\begin{array}{l}\text { MnSOD mRNA } \\
\left(2^{-\Delta \Delta c t}\right)\end{array}$ & & $0.537 \pm 0.17$ & $0.514 \pm 0.21$ & $0.547 \pm 0.15$ & 0.796 \\
\hline $\begin{array}{l}\text { MnSOD } \\
\text { protein [pg/ml] }\end{array}$ & & $170.57 \pm 63.25$ & $166.23 \pm 76.36$ & $172.35 \pm 57.38$ & 0.731 \\
\hline $\begin{array}{l}\text { MPO mRNA } \\
\left(2^{-\Delta \Delta t}\right)\end{array}$ & & $0.319 \pm 0.04$ & $0.321 \pm 0.04$ & $0.318 \pm 0.04$ & 0.844 \\
\hline $\begin{array}{l}\text { MPO protein } \\
{[\mathrm{ng} / \mathrm{ml}]}\end{array}$ & & $313.32 \pm 40.49$ & $315.71 \pm 33.78$ & $312.33 \pm 43.23$ & 0.834 \\
\hline $\begin{array}{l}\text { COX-2 mRNA } \\
\left(2^{-\Delta \Delta c t}\right) \\
\end{array}$ & & $0.237 \pm 0.04$ & $0.241 \pm 0.03$ & $0.235 \pm 0.04$ & 0.409 \\
\hline $\begin{array}{l}\text { COX-2 protein } \\
{[\mathrm{ng} / \mathrm{ml}]}\end{array}$ & & $113.69 \pm 21.56$ & $116.47 \pm 20.67$ & $112.55 \pm 22.01$ & 0.491 \\
\hline $\begin{array}{l}\text { iNOS mRNA } \\
\left(2^{-\Delta \Delta c t}\right)\end{array}$ & & $0.102 \pm 0.02$ & $0.11 \pm 0.02$ & $0.10 \pm 0.02$ & 0.623 \\
\hline $\begin{array}{l}\text { iNOS protein } \\
{[\mathrm{ng} / \mathrm{ml}]}\end{array}$ & & $20.73 \pm 8.51$ & $21.85 \pm 9.49$ & $20.27 \pm 8.13$ & 0.749 \\
\hline $\begin{array}{l}\text { MMP-2 mRNA } \\
\left(2^{-\Delta \Delta t}\right)\end{array}$ & & $284.27 \pm 9.35$ & $287.16 \pm 9.34$ & $282.97 \pm 9.13$ & $0.039^{*}$ \\
\hline $\begin{array}{l}\text { MMP-2 protein } \\
{[\mathrm{ng} / \mathrm{ml}]}\end{array}$ & & $363.51 \pm 20.52$ & $364.87 \pm 22.28$ & $358.48 \pm 21.51$ & 0.133 \\
\hline $\begin{array}{l}\text { MMP-9 } \\
\text { mRNA }\left(2^{-\Delta \Delta c t}\right)\end{array}$ & & $291.96 \pm 11.02$ & $293.55 \pm 12.01$ & $291.25 \pm 10.56$ & 0.423 \\
\hline $\begin{array}{l}\text { MMP-9 protein } \\
{[\mathrm{ng} / \mathrm{ml}]}\end{array}$ & & $360.46 \pm 21.84$ & $364.87 \pm 22.28$ & $358.48 \pm 21.51$ & 0.186 \\
\hline
\end{tabular}

$E D-I$ - first depressive episode, rDE - recurrent depressive episodes, SD - standard deviation, ${ }^{*} p$ statistically significant, MnSOD manganese superoxide dismutase, MPO - myeloperoxidase, COX-2 - cyclooxygenase 2, iNOS - inducible nitric oxide synthase, MMP-2 - metalloproteinase 2, MMP-9-metalloproteinase 9.

ogy. In his opinion, it means that the immune and affective systems are dynamic systems, subject to constant changes, but constituting the mirror reflection of one another. The interaction between the immune system and emotions is evidenced by the frequency of emotional disorders in patients with immune system diseases and deterioration of the immune system in patients with var- ious groups of mental disorders [35]. D'Acquisto stresses that the variability of the two systems is expressed in their plasticity, understood as the ability to change (adapt) under the influence of extrinsic factors. Both in the case of the immune system and the affective system, by means of changes in the DNA chain, we obtain from our ancestors only a biological predisposition determin- 
Table III. Results of Spearman's rank correlation for the variables analysed

\begin{tabular}{|c|c|c|c|c|c|c|c|}
\hline \multirow[t]{2}{*}{ Variable } & & \multicolumn{2}{|c|}{$\begin{array}{l}\text { All subjects } \\
(N=104)\end{array}$} & \multicolumn{2}{|c|}{$\begin{array}{c}\text { ED-I } \\
(N=34)\end{array}$} & \multicolumn{2}{|c|}{$\begin{array}{c}\mathrm{rDE} \\
(N=70)\end{array}$} \\
\hline & & $R$ Spearman & $P$-value & $R$ Spearman & $P$-value & $R$ Spearman & $P$-value \\
\hline \multirow[t]{3}{*}{ MnSOD mRNA $\left(2^{-\Delta \Delta c t}\right)$} & \& Hypochondria & -0.226 & 0.056 & -0.022 & 0.923 & -0.311 & $0.026^{*}$ \\
\hline & \& Depression & -0.207 & 0.082 & -0.033 & 0.887 & -0.310 & $0.027^{\star}$ \\
\hline & \& Hysteria & -0.162 & 0.175 & -0.082 & 0.725 & -0.264 & 0.062 \\
\hline \multirow[t]{3}{*}{ MnSOD protein $[\mathrm{pg} / \mathrm{ml}]$} & \& Hypochondria & -0.229 & 0.053 & -0.024 & 0.916 & -0.324 & $0.020^{*}$ \\
\hline & \& Depression & -0.168 & 0.159 & -0.001 & 0.996 & -0.257 & 0.068 \\
\hline & \& Hysteria & -0.151 & 0.204 & -0.063 & 0.787 & -0.257 & 0.069 \\
\hline \multirow[t]{3}{*}{ MPO mRNA $\left(2^{-\Delta \Delta c t}\right)$} & \& Hypochondria & 0.222 & 0.060 & 0.188 & 0.414 & 0.257 & 0.068 \\
\hline & \& Depression & 0.136 & 0.254 & 0.189 & 0.412 & 0.131 & 0.359 \\
\hline & \& Hysteria & 0.220 & 0.064 & 0.104 & 0.655 & 0.255 & 0.071 \\
\hline \multirow[t]{3}{*}{ MPO protein [ng/ml] } & \& Hypochondria & 0.245 & $0.038^{\star}$ & 0.203 & 0.377 & 0.284 & $0.044^{*}$ \\
\hline & \& Depression & 0.155 & 0.193 & 0.226 & 0.325 & 0.153 & 0.285 \\
\hline & \& Hysteria & 0.233 & 0.049 & 0.109 & 0.639 & 0.276 & $0.049^{\star}$ \\
\hline \multirow[t]{3}{*}{ COX-2 mRNA $\left(2^{-\Delta \Delta c t}\right)$} & \& Hypochondria & 0.013 & 0.913 & 0.101 & 0.663 & 0.096 & 0.502 \\
\hline & \& Depression & 0.116 & 0.334 & 0.407 & 0.067 & 0.089 & 0.536 \\
\hline & \& Hysteria & 0.006 & 0.959 & -0.024 & 0.917 & 0.036 & 0.804 \\
\hline \multirow[t]{3}{*}{ COX-2 protein $[\mathrm{ng} / \mathrm{ml}]$} & \& Hypochondria & 0.050 & 0.675 & 0.033 & 0.887 & 0.103 & 0.470 \\
\hline & \& Depression & 0.152 & 0.203 & 0.432 & 0.051 & 0.113 & 0.429 \\
\hline & \& Hysteria & 0.051 & 0.672 & 0.088 & 0.703 & 0.059 & 0.681 \\
\hline \multirow[t]{3}{*}{ iNOS mRNA $\left(2^{-\Delta \Delta c t}\right)$} & \& Hypochondria & 0.139 & 0.244 & 0.247 & 0.281 & 0.106 & 0.460 \\
\hline & \& Depression & 0.013 & 0.911 & 0.006 & 0.980 & 0.023 & 0.872 \\
\hline & \& Hysteria & 0.129 & 0.279 & 0.347 & 0.123 & 0.052 & 0.717 \\
\hline \multirow[t]{3}{*}{ iNOS protein [ng/ml] } & \& Hypochondria & 0.095 & 0.426 & 0.233 & 0.310 & 0.059 & 0.681 \\
\hline & \& Depression & 0.003 & 0.977 & 0.016 & 0.946 & 0.002 & 0.991 \\
\hline & \& Hysteria & 0.104 & 0.384 & 0.349 & 0.122 & -0.025 & 0.861 \\
\hline \multirow[t]{3}{*}{ MMP-2 mRNA $\left(2^{-\Delta \Delta c t}\right)$} & \& Hypochondria & -0.097 & 0.349 & -0.070 & 0.718 & -0.059 & 0.635 \\
\hline & \& Depression & -0.128 & 0.217 & -0.040 & 0.837 & -0.064 & 0.612 \\
\hline & \& Hysteria & -0.169 & 0.102 & -0.071 & 0.713 & -0.093 & 0.458 \\
\hline \multirow[t]{3}{*}{ MMP-2 protein [ng/ml] } & \& Hypochondria & -0.186 & 0.072 & -0.180 & 0.350 & -0.159 & 0.202 \\
\hline & \& Depression & -0.301 & $0.003^{*}$ & -0.155 & 0.423 & -0.319 & $0.009^{*}$ \\
\hline & \& Hysteria & -0.228 & $0.027^{*}$ & -0.319 & 0.092 & -0.131 & 0.294 \\
\hline \multirow[t]{3}{*}{ MMP-9 mRNA $\left(2^{-\Delta \Delta c t}\right)$} & \& Hypochondria & 0.024 & 0.817 & -0.042 & 0.831 & 0.059 & 0.637 \\
\hline & \& Depression & -0.150 & 0.146 & -0.137 & 0.479 & -0.142 & 0.254 \\
\hline & \& Hysteria & 0.035 & 0.736 & -0.165 & 0.392 & 0.142 & 0.254 \\
\hline \multirow[t]{3}{*}{ MMP-9 protein [ng/ml] } & \& Hypochondria & -0.176 & 0.089 & -0.108 & 0.579 & -0.164 & 0.189 \\
\hline & \& Depression & -0.323 & $0.001^{*}$ & -0.295 & 0.121 & -0.300 & $0.014^{*}$ \\
\hline & \& Hysteria & -0.122 & 0.237 & -0.076 & 0.693 & -0.077 & 0.538 \\
\hline
\end{tabular}

ED-I - first depressive episode, $r D E$ - recurrent depressive episodes, ${ }^{*} p$ statistically significant, MnSOD - manganese superoxide dismutase, MPO - myeloperoxidase, COX-2 - cyclooxygenase 2, iNOS - inducible nitric oxide synthase, MMP-2 - metalloproteinase 2, MMP-9 metalloproteinase 9. 
Table IV. Inflammatory process indicators and personality traits

\begin{tabular}{|c|c|}
\hline 个 IL-1 & $\begin{array}{c}\uparrow \text { Hypochondria } \\
\uparrow \text { Hysteria } \\
\uparrow \text { Depression } \\
\uparrow \text { Welsh's anxiety [20] }\end{array}$ \\
\hline 个 IL-6 & $\begin{array}{c}\uparrow \text { Neuroticism [37] } \\
\downarrow \text { Conscientiousness [37] } \\
\downarrow \text { Openness to experience [38] } \\
\uparrow \text { Impulsiveness [36] }\end{array}$ \\
\hline$\uparrow$ IL-10 & $\begin{array}{c}\uparrow \text { Hypochondria } \\
\uparrow \text { Hysteria } \\
\uparrow \text { Depression } \\
\uparrow \text { Welsh's anxiety [20] }\end{array}$ \\
\hline$\uparrow$ IL-12 & $\begin{array}{c}\uparrow \text { Hypochondria } \\
\uparrow \text { Hysteria } \\
\uparrow \text { Depression } \\
\uparrow \text { Welsh's anxiety [20] }\end{array}$ \\
\hline$\uparrow \mathrm{CRP}$ & $\begin{array}{c}\uparrow \text { Neuroticism [37] } \\
\downarrow \text { Conscientiousness [36] } \\
\downarrow \text { Openness to experience [39] } \\
\uparrow \text { Hostility [40] } \\
\uparrow \text { Impulsiveness [36] } \\
\uparrow \text { Anxious attitude in reality evaluation } \\
\quad[43] \\
\downarrow \text { Self-control [43] }\end{array}$ \\
\hline$\uparrow$ TNF- $\alpha$ & $\uparrow$ Hostility $[41,42]$ \\
\hline
\end{tabular}

ing the risk of incidence of a given disease. Our ability to adapt (diet, lifestyle, but also our ability to cope) determines whether or not the disease manifests itself. D'Acquisto also introduces the concept of immunological personality, asking the question of its convergence with psychological personality. It seems that the answer to this question may be in the affirmative. The personality trait important for the activation of the immune system is neuroticism, which mediates the psychological response to stress stimuli [34]. Table IV shows the relationships described in the literature between personality traits and the indicators of an active inflammatory process [20, 36-43].

\section{Early childhood experiences and personality traits}

Many authors stress the importance of early childhood experiences, especially those with trauma traits, for the development of mental disorders in adult life. We can find papers indicating a direct connection between trauma from childhood and abuse of psychoactive substances, psychosis, mood disorders, anxiety disorders and the risk of attempted suicide [44]. These experiments lead to changes in the reactivity of the hormonal system and immune system, to changes in brain function (mainly in the frontal cortex and the hippocampus area) and, at the psychological level, to the persistence of non-adaptive ways of reacting to stressors [45]. In mood disorders, early lifetime trauma is associated with increased inflammatory, as measured with CRP, and nitro-oxidative stress [46]. The latter is based on pathways of nervous connections reinforced by repeating sensory experiences, both those of positive and traumatic character. Creating and reinforcing nervous connections is a key task in the early stages of brain development and forms the foundations of personality.

A particularly important need for each of us is the need for a relationship with another person. It is just as important to us as the need to satisfy hunger and thirst. Loneliness strongly motivates us to change this state [47]. Insufficient satisfaction of the need for proximity in the early stages of a child's life (e.g. due to social isolation, low parental skills, emotional rejection of the child by parents) leads to changes in neurobehavioural responses to experienced stress, which shape patterns of our future relationships with people [48]. This forms a depressive attitude when there is no response to an attempt to satisfy the need, and when there is frustration not only in terms of the psychological response but also in terms of the immune response. It may turn out that subsequent unsuccessful attempts at satisfying a specific problem (crying, screaming) will be considered too burdensome by the child, and hence will shape the passive attitude. Such behaviour influences the development of the immune response; when mobilisation of the body becomes too burdensome, the body reacts with no mobilisation, which explains to some extent the reduced immunity in people with depression and the occurrence of a depressive reaction in people with the diagnosis of autoimmune diseases. At the same time, the hormonal and immune systems are deregulated through the network of mutual feedback in the hypothalamic-pituitary-adrenal axis (HPA axis). A confirmation of the interaction of these systems, not only from the developmental point of view, but also from the perspective of occurrence of symptoms, is the convergence of the frequency of occurrence of both mental disorders (anxiety disorders, mood disorders) and autoimmune disorders (rheumatoid arthritis, Sjögren syndrome, multiple sclerosis), which takes place between 30 and 50 years of age $[49,50]$.

Moreover, through epigenetic mechanisms, these patterns may be passed on to future generations. This relationship was confirmed by Saavedra-Rodríguez and Feig [51]. In the latter study, male and female mice were subjected to social stress during their early childhood and adolescence, in the form of instability and the need to fight for social position. These factors not only changed the anxiety behaviours of the animals 
examined, but were also passed on to the next three generations through epigenetic changes. Curzytek et al. [52] reported that "pessimism" in animal models is associated with an inflammatory response as indicated by increased production of IL-1 $\beta$, IL-4 and IFN. In the studies by Koutra et al. [53], it was demonstrated that the severity of postnatal depression symptoms in the mother and the degree of anxiety she experienced as a permanent feature of her personality were related to the quality of neuropsychological development in children. Emotional proximity between parents and children during early childhood was a factor significantly affecting the cortex volume in the offspring's frontal gyrus area and correlated with personality traits conducive to depression in children [54]. Interestingly, changes were observed at the micro-RNA level and in the expression of genes in reproductive cells of males affected by short-term but severe stress stimuli [55]. These changes co-existed and correlated with anxiety behaviour found in these individuals. Similar epigenetic modifications were found in the brains of their offspring, which were not themselves subjected to stress stimuli.

\section{Summary}

When analysing the relationship between personality traits and the immune system, it is worth considering whether the traits of our personality define our later diseases in an unchangeable way, being a kind of a life sentence, over which we have no influence. Are people with neurotic features doomed to evolutionary failure? It turns out that for thousands of years of the human race's development, the anxious attitude has been conducive to survival. Our ancestors were more vigilant and focused on anticipating potential threats, which allowed them to avoid risks more effectively. Today, in an environment that is objectively assessed as low risk, a neurotic person will continue to be overly vigilant, consuming his or her immune resources pointlessly [56]. In this pessimistic approach, however, it turns out that the level of intelligence is a mediator and a specific protective factor between the neurotic trait and the risk of depression [57]. Therefore, the maturity of the frontal lobes, strengthening their development and improvement of their functioning should be the therapeutic goal, regarding both pharmacotherapy and psychotherapy. However, the influence of personality is only one side of the coin. The question of how the immune system influences the formation of personalities and whether this path can be a new aspect in the treatment of depression is still open. Many researchers stress the impact of the inflammatory process, which is associated both with stress in the form of patho- gens and with the onset of psychological stress. The answer may be contained in the immune system's response to the stress stimulus, i.e. its ability to cope or not. The influence of oxidative factors at early stages of development may lead to epigenetic changes related to a decreased ability to mobilise the body, which leads to a prolonged inflammatory reaction. This aspect of looking at the development of depression could, for example, explain why some people with diabetes will experience a depressive episode and others will not. However, this direction of studies on the development of depressive disorders still requires a lot of research and analysis, which may contribute to new ways of treatment, especially of recurrent depressive disorders.

The obtained data indicate that an increase of the size of the studied group may be important for the accuracy of the results.

In conclusion, scales for the neurotic triad of the MMPI-2 test correlate significantly with the expression at the level of mRNA and protein for MnSOD, MPO and metalloproteinases 2 and 9 in the group of patients with symptoms of depression.

\section{Acknowledgments}

Monika Talarowska and Małgorzata Kowalczyk - equivalent share of the authors in the compilation of this paper.

This study was supported with scientific research grants from Medical University of Lodz No. 503/5-062-02/503-51-010-18.

\section{Conflict of interest}

The authors declare no conflict of interest.

\section{References}

1. Talarowska M, Galecki P. Cognition and emotions in recurrent depressive disorders - the role of inflammation and the kynurenine pathway. Curr Pharm Des 2016; 22: 955-62.

2. Sowa-Kućma M, Styczeń K, Siwek M, et al. Lipid peroxidation and immune biomarkers are associated with major depression and its phenotypes, including treatment-resistant depression and melancholia. Neurotox Res 2018; 33: 448-60.

3. Bica T, Castelló R, Toussaint LL, Montesó-Curto P. Depression as a risk factor of organic diseases: an international integrative review. J Nurs Scholarsh 2017; 49: 389-99.

4. Maes M, Van Gastel A, Delmeire L, Kenis G, Bosmans E, Song C. Platelet alpha2-adrenoceptor density in humans: relationships to stress-induced anxiety, psychasthenic constitution, gender and stress-induced changes in the inflammatory response system. Psychol Med 2002; 32: 919-28.

5. Docherty AR, Edwards AC, Yang F, et al. Age of onset and family history as indicators of polygenic risk for major depression. Depress Anxiety 2017; 34: 446-52. 
6. Maes M, Leonard B, Fernandez A, et al. (Neuro)inflammation and neuroprogression as new pathways and drug targets in depression: from antioxidants to kinase inhibitors. Prog Neuropsychopharmacol Biol Psychiatry 2011; 35: 659-63.

7. Pandey GN. Inflammatory and innate immune markers of neuroprogression in depressed and teenage suicide brain. Mod Trends Pharmacopsychiatry 2017; 31: 79-95.

8. Su KP. Inflammation in psychopathology of depression: clinical, biological, and therapeutic implications. Bio Medicine 2012; 2: 68-74.

9. Talarowska M, Szemraj J, Berk M, Maes M, Gałecki P. Oxidant/antioxidant imbalance is an inherent feature of depression. BMC Psychiatry 2015; 15: 71.

10. Gałecki P, Talarowska M. Neurodevelopmental theory of depression. Prog Neuropsychopharmacol Biol Psychiatry 2018; 80: 267-72.

11. Pingault JB, Falissard B, Côté S, Berthoz S. A new approach of personality and psychiatric disorders: a short version of the Affective Neuroscience Personality Scales. PLoS One 2012; 7 : e41489.

12. Bukh JD, Andersen PK, Kessing LV. Personality and the long-term outcome of first-episode depression: a prospective 5-year follow-up study. J Clin Psychiatry 2016; 77: e704-10.

13. International Statistical Classification of Diseases and Related Health Problems 10th Revision (ICD-10). World Health Organization, Genewa 2015.

14. Ettinger RH. Psychopharmacology Second Edition. Taylor \& Francis, 2017.

15. Hamilton M. A rating scale for depression. J Neurol Neurosurg Psychiatry 1960; 23: 56-62.

16. Demyttenaere K, De Fruyt J. Getting what you ask for: on the selectivity of depression rating scales. Psychothery Psychosom 2003; 72: 61-70.

17. Kucharski T. Selected issues connected with polish adaptation of the MMPI-2 and the MMPI-A. CPKiROZ, Toruń 2002.

18. Hathaway SR, McKinley JC. The Minnesota Multiphasic Personality Inventory. University of Minnesota Press, Minneapolis 1943.

19. Talarowska M, Florkowski A, Zboralski K, Gałecki P. Differences in the course of depressive disorders among women and men measured by MMPI-2. Psychiatr Pol 2010; 44: 319-28.

20. Talarowska M, Bliźniewska K, Szemraj J, Kowalczyk M, Gałecki P. Personality traits as a possible factor in the inflammatory response in the first depression episode and in recurrent depressive disorders. Eur J Psychiatry 2018; 32: 63-71.

21. Schmittgen TD, Livak KJ. Analyzing real-time PCR data by the comparative CT method. Nat Protoc 2008; 3: 1101-8.

22. Livak K, Schmittgen TD. Analysis of relative gene expression data using real-time quantitative PCR and the 2$\Delta \Delta C T$ method. Methods 2001; 25: 402-8.

23. Kirkwood B, Sterne J. Essential medical statistics. $2^{\text {nd }}$ edn. Wiley-Bleckwell 2003.

24. Talarowska M, Orzechowska A, Szemraj J, Su KP, Maes M, Gałecki P. Manganese superoxide dismutase gene expression and cognitive functions in recurrent depressive disorder. Neuropsychobiology 2014; 70: 23-8.

25. Talarowska M, Szemraj J, Gałecki P. Myeloperoxidase gene expression and cognitive functions in depression. Adv Med Sci 2015; 60: 1-5.

26. Gałecki P, Talarowska M, Bobińska K, Szemraj J. COX-2 gene expression is correlated with cognitive function in recurrent depressive disorder. Psychiatry Res 2014; 215 . 488-90.

27. Talarowska $M$, Bobińska K, Zajączkowska M, Su KP, Maes M, Gałecki P. Impact of oxidative/nitrosative stress and inflammation on cognitive functions in patients with recurrent depressive disorders. Med Sci Monit 2014; 20: 110-5.

28. Bobińska K, Szemraj J, Gałecki P, Talarowska M. The role of MMP genes in recurrent depressive disorders and cognitive functions. Acta Neuropsychiatr 2016; 28: 221-31.

29. Penner J, Ford KA, Taylor R, et al. Medial prefrontal and anterior insular connectivity in early schizophrenia and major depressive disorder: a resting functional MRI evaluation of large-scale brain network models. Front Hum Neurosci 2016; 10: 132.

30. Delaveau P, Jabourian M, Lemogne C, Guionnet S, Bergouignan L, Fossati P. Brain effects of antidepressants in major depression: a meta-analysis of emotional processing studies. J Affect Disord 2011; 130: 66-74.

31. Hamlat EJ, Connolly SL, Hamilton JL, Stange JP, Abramson LY, Alloy LB. Rumination and overgeneral autobiographical memory in adolescents: an integration of cognitive vulnerabilities to depression. J Youth Adolesc 2015; 44: 806-18.

32. Euteneuer F, Dannehl K, Del Rey A, Engler H, Schedlowski $M$, Rief W. Peripheral immune alterations in major depression: the role of subtypes and pathogenetic characteristics. Front Psychiatry 2017; 8: 250.

33. Polikandrioti M, Tzirogiannis K, Zyga S, et al. Effect of anxiety and depression on the fatigue of patients with a permanent pacemaker. Arch Med Sci Atheroscler Dis 2018; 3: 8-17.

34. D'Acquisto F. Affective immunology: where emotions and the immune response converge. Dialogues Clin Neurosci 2017; 19: 9-19.

35. Rubinow KB, Rubinow DR. In immune defense: redefining the role of the immune system in chronic disease. Dialogues Clin Neurosci 2017; 19: 19-26.

36. Isung J, Aeinehband S, Mobarrez F, et al. High interleukin-6 and impulsivity: determining the role of endophenotypes in attempted suicide. Transl Psychiatry 2014; 4: e470.

37. Sutin AR, Terracciano A, Deiana B, et al. High neuroticism and low conscientiousness are associated with interleukin-6. Psychol Med 2010; 40: 1485-93.

38. Chapman BP, van Wijngaarden E, Seplaki CL, Talbot N, Duberstein P, Moynihan J. Openness and conscientiousness predict 34-week patterns of interleukin-6 in older persons. Brain Behav Immun 2011; 25: 667-73.

39. Luchetti M, Barkley JM, Stephan Y, Terracciano A, Sutin AR. Five-factor model personality traits and inflammatory markers: new data and a meta-analysis. Psychoneuroendocrinology 2014; 50: 181-93.

40. Smith TW, Uchino BN, Bosch JA, Kent RG. Trait hostility is associated with systemic inflammation in married couples: an actor-partner analysis. Biol Psychol 2014; 102: $51-3$

41. Boisclair Demarble J, Moskowitz DS, Tardif JC, D’Antono $B$. The relation between hostility and concurrent levels of inflammation is sex, age, and measure dependent. J Psychosom Res 2014; 76: 384-93.

42. Girard D, Tardif JC, Boisclair Demarble J, D’Antono B. Trait hostility and acute inflammatory responses to stress in the laboratory. PLoS One 2016; 11: e0156329.

43. Henningsson S, Baghaei F, Rosmond R, et al. Association between serum levels of $C$-reactive protein and personality traits in women. Behav Brain Funct 2008; 4: 16.

44. Aas M, Henry C, Andreassen OA, Bellivier F, Melle I, Etain $B$. The role of childhood trauma in bipolar disorders. Int J Bipolar Disord 2016; 4: 2. 
45. Nagy C, Vaillancourt K, Turecki G. A role for activity dependent epigenetics in the development and treatment of major depressive disorder. Genes Brain Behav 2018; 17: e12446.

46. Moraes JB, Maes M, Roomruangwong C, et al. In major affective disorders, early life trauma predict increased nitro-oxidative stress, lipid peroxidation and protein oxidation and recurrence of major affective disorders, suicidal behaviours and a lowered quality of life. Metab Brain Dis 2018; 33: 1081-96.

47. Cacioppo JT, Cacioppo S, Boomsma DI. Evolutionary mechanisms for loneliness. Cogn Emot 2014; 28: 3-21.

48. Kinnally EL, Capitanio JP. Paternal early experiences influence infant development through non-social mechanisms in Rhesus Macaques. Front Zool 2015; 12 Suppl 1 S14.

49. Leber A, Teles A, Zenclussen A. Regulatory $T$ cells and their role in pregnancy. Am J Reprod Immunol 2010; 63: 445-59.

50. Kessler RC, Amminger GP, Aguilar-Gaxiola S, Alonso J, Lee S, Ustun TB. Age of onset of mental disorders: a review of recent literature. Curr Opin Psychiatry 2007; 20: 359-64.

51. Saavedra-Rodríguez L, Feig LA. Chronic social instability induces anxiety and defective social interactions across generations. Biol Psychiatry 2013; 73: 44-53.

52. Curzytek K, Kubera M, Trojan E, et al. The effects of pessimism on cell-mediated immunity in rats. Prog Neuropsychopharmacol Biol Psychiatry 2018; 80: 295-303.

53. Koutra K, Roumeliotaki T, Kyriklaki A, et al. Maternal depression and personality traits in association with child neuropsychological and behavioral development in preschool years: mother-child cohort (Rhea Study) in Crete, Greece. J Affect Disord 2017; 217: 89-98.

54. Yang J, Yin P, Wei D, Wang K, Li Y, Qiu J. Effects of parental emotional warmth on the relationship between regional gray matter volume and depression-related personality traits. Soc Neurosci 2017; 12: 337-48.

55. Dias BG, Ressler KJ. Parental olfactory experience influences behavior and neural structure in subsequent generations. Nat Neurosci 2014; 17: 89-96.

56. Montag C, Panksepp J. Primary emotional systems and personality: an evolutionary perspective. Front Psychol 2017; 8: 464.

57. Navrady LB, Ritchie SJ, Chan SW, et al. Intelligence and neuroticism in relation to depression and psychological distress: evidence from two large population cohorts. Eur Psychiatry 2017; 43: 58-65. 